\title{
Saeculum-Mundus Politik Indonesia: Satu Kajian Filosofis dalam Perspektif Nurcholish Madjid
}

\section{Imron Mustofa}

Perbandingan Madzhab, Fakultas Syariah dan Hukum, UIN Sunan Ampel Surabaya imron_mustofa@uinsby.ac.id

Naskah diterima: 8 Februari 2021; direvisi: 28 Juli 2021; disetujui: 29 Juli 2021

\begin{abstract}
This article suggests some common opinions on Muslim's worldview, which became the center of contention. This gives rise to perspective which states that the religion participation in government will bring the world of politics into the arena of theocentrism that ends in authoritarianism. The research is qualitative, based on library research. The approach used is descriptive critical analysis. It aims to describe factual dynamics on Indonesian social-politic from philosophical point of view. The research finds that, on the second half of twentieth century, Nurcholish Madjid's renewal idea on Islamic political thought (secularization) gets a variety of responses. Madjid suggested the need to separate religion from social-politic arena with his slogan, 'Islam Yes, Islamic party No'. The basis of the idea is built on the concept of rationality as the main authority in the social science paradigm. Ideas or dogma, meanwhile, is part of historical development which has to be submissive to conditions that always change. Everything that "exist" has to change, the only absolute one is the change itself.
\end{abstract}

Keywords: authoritarianism; Indonesian politics; logic of science; Nurcholish Madjid; principle of identity.

\begin{abstract}
Abstrak
Artikel ini menyuguhkan beberapa pandangan umum mengenai posisi cara pandang Muslim yang menjadi rebutan. Hal ini memunculkan perspektif yang menyatakan bahwa turut sertanya agama dalam pemerintahan akan membawa dunia perpolitikan dalam kancah teosentrisme, yang berakhir pada otoritarianisme. Jenis artikel ini kualitatif, berbentuk studi kepustakaan (library research). Pendekatan yang dipergunakan adalah deskriptif analisis kritis. Tujuannya memotret dinamika aktual sosio politik di Indonesia dari kaca mata analisis filosofis. Penelitian ini mengkonfirmasi bahwa pada paruh kedua abad kedua puluh, Nurcholish Madjid melalui "sekularisasi" pembaharuan pemikiran politik Islam menuai berbagai reaksi. Madjid memandang perlunya agama untuk dipisahkan dari sosial-politik, slogannya Islam yes, partai Islam no. Basis gagasannya dibangun dari konsep rasionalitas sebagai pemegang otoritas utama dalam paradigma sains sosial. Sedangkan dogma dalam kehidupan manusia juga merupakan bagian dari proses perkembangan sejarah, harus tunduk pada perubahan zaman. Segala eksistensi niscaya akan berubah, satu-satunya yang tidak berubah adalah perubahan itu sendiri.
\end{abstract}

Kata Kunci: otoritarianisme; politik Indonesia; logika saintifik; Nurcholish Madjid; prinsip identitas.

\section{Pendahuluan}

Pada medio paruh kedua abad ke-20, tampaknya merupakan periode krusial bagi perhelatan pemikiran Islam di Indonesia. Tahun-tahun tersebut diwarnai dengan 
perkembangan pemikiran dengan jargon utamanya "membuka pintu semangat ijtihad pada semua dimensi Islam." Kebebasan pribadi menjadi diutamakan, dan pembebasan dari struktur sosial-politik yang dinilai menindas sebagai tujuan. (Rahman, 1984, p. 13; Esposito, et al., 2000) Semangat ini melahirkan suatu gerakan "multikulturalisme" yang menyamakan status semua kebudayaan dalam ranah publik tanpa adanya diskriminasi. (Stodard, t.t., pp. 341-343) Gerakan ini dikenal sebagai sekularisasi pemikiran Islam. Tokoh utama dalam gerakan ini adalah Nurcholish Madjid. Pengaruh cara pandang yang dilontarkan Cak Nur ini tidak hanya berputar pada wilayah politik, sosial dan ekonomi, namun juga telah menjamur dan menghinggapi lembaga pendidikan dan pola berpikir Muslim. Bentuk implikasi logis dari gaya berpikir sekular ini dinilai cenderung menekankan pengembangan kemampuan rasio, perlindungan hak, toleransi agama, kebebasan serta mengidentifikasi dan memecahkan problematika yang dihadapi dalam hidup.

Persoalan ini dimulai dari bagaimana kata sekularisasi didefinisikan. Secara etimologis, istilah ini berasal dari bahasa latin saeculum, bermakna masa, waktu, atau abad (age, century, eewu, siecle), jadi istilah sekular berkaitan dengan masalah waktu. Pardoyo mengartikan sekular sebagai sebuah periode tertentu di dunia, yang diakibatkan proses sejarah. (Pardoyo, 1993, p. 20) Tidak berbeda, Madjid menggambarkan etimologi sekular sebagai kata Latin yang berarti dunia, dengan sinonimnya mundus. Hal ini berkonotasi bahwa, manusia menurut Madjid adalah makhluk yang hidup di dunia. Madjid menambahkan, bahwa meskipun dalam permulaan sejarah penggunaannya, kata sekular berdenotasi negatif, rendah dan hina, namun lama kelamaan pengertian yang negatif itu dalam dunia pemikiran Barat telah berkurang bahkan lenyap. Oleh sebab itu, sekularisasi dapat diartikan sebagai proses penduniawian, (Madjid, 1987, pp. 216-218) dan oleh karena makna negatifnya telah lenyap, maka umat Islam tidak boleh terus-menerus memandang buruk kata sekuler. Oleh karena, manusia adalah makhluk duniawi, maka Madjid menilai sah-sah saja menggunaan terma sekular untuk Islam, karena Islam memasang agama yang ada di dunia adapun manusia memang benar-benar makhluk sekular. Dengan demikian, Islam sekular adalah suatu proses perjalanan Islam, yang sangat berkaitan dengan perubahan problematika masyarakat khususnya yang sedang dalam proses menuju modernisasi. Adapun mengenai perubahan makna dari sekular menjadi sekularisasi, penulis tidak menemukan penjelasan yang memadai dari tulisan Madjid.

Madjid membedakan pengertian sekularisasi dan sekularisme. Sekularisasi menurutnya merupakan suatu proses desakralisasi segala aspek yang bersifat duniawi dan sementara. (Madjid, 1987, p. 219) Adapun sekularisme, baginya merupakan suatu ideologi 
yang mengajarkan bahwa moralitas harus semata-mata ditumpukan pada kebaikan manusia di dunia, hingga menafikan pertimbangan-pertimbangan yang diambil berdasarkan keyakinan akan Tuhan. (Nasution, 1997, p. 189) Dengan kata lain, sekularisasi bersifat inklusif, sementara itu sekularisme lebih bersifat eksklusif.

Madjid menganalogikan perbedaan sekular dan sekularisme seperti perbedaan antara rasio dan rasionalisme. Seorang Muslim harus bersikap rasional, namun tidak sepatutnya menjadi pendukung rasionalisme. Rasio-[nalitas; nalisasi] adalah [metode; proses penggunaan metode] dalam memperoleh pengertian dan penilaian yang tepat tentang suatu masalah dan pemecahannya. Lanjutnya, batasan antara rasionalisasi dengan rasionalisme adalah adanya kepercayaan akan adanya akhirat dan prinsip-prinsip ketuhanan. Artinya, jika rasionalisme tidak terbatas apa pun, maka rasionalisasi terbatas dan dapat diperbaiki melalui kepercayaan akan akhirat dan prinsip ketuhanan. Begitu pula dengan sekularisasi yang terbatas, adapun sekularisme tidak terbatas. (Madjid, 1970, p. 2) Oleh karenanya, sekularisme harus ditolak, sebaliknya sekularisasi merupakan suatu keharusan bagi seorang muslim.

Dalam perkembangannya karena banyaknya resistensi yang ditunjukkan banyak cendekiawan Muslim di Indonesia Madjid tampak berusaha merevisi definisi sekularisasi. Pada tahun 1985, melalui karyanya "Sekularisasi Ditinjau Kembali," Madjid berusaha memisahkan sekularisasi dalam kacamata sosiologis dan filosofis. Pengertian sekularisasi sebagai mana dijabarkan di atas oleh Madjid kategorikan sebagai pengertian filosofis. Adapun dalam istilah sosiologis, sekularisasi mengandung pengertian; "pembebasan," yaitu, suatu yaitu pembebasan dari sikap penyucian yang tidak pada tempatnya. Pada makna ini, sekularisasi menjadi sebuah proses desakralisasi objek-objek yang semestinya tidak disakralkan. Di sini, Madjid tampak ingin mengartikan sekularisasi sebagai usaha pemberantasan bid'ah, khurafāt dan praktek shirk. (Madjid, 1987, pp. 258-259) Keterangan tersebut sampai pada kesimpulan adanya “oposisi biner" dalam pemaknaan kata sekularisasi. Ia digambarkan sebagai framework berpikir dengan karakteristik khas yang mencakup; pertama, kemampuan beretorika dengan memanfaatkan rasionalitas dan "liberalisasi" ide yang digulirkan. Kedua, cenderung merelatifkan nilai kebenaran "spekulasi" akademis. Ketiga, menegaskan pemisahan antara agama sebagai fenomena sejarah dengan agama sebagai dogma. Jika dogma digambarkan sebagai cara pandang top down, maka sebaliknya fenomena sejarah ataupun kajian ilmiah digambarkan sebagai bottom up. Meminjam ungkapan Richard Rorty dalam Philosophy and The Mirror of Nature bahwa hakikat sains yang selalu berubah-ubah adalah tidak memiliki hakikat. (Rorty, 1980, pp. 88-89, 377-378) 
Singkatnya tidak ada apa yang disebut teori-teori ilmu pengetahuan yang mapan, semua hanya "spekulasi" akademis belaka, adapun peran dogma ada pada individu bukan sosialpolitik masyarakat.

Fenomena ini tentu menarik untuk dikaji secara komprehensif, dalam rangka menemukan ada-tidaknya benang merah yang mengikat sekularisasi Madjid dengan ide-ide pemikir "Barat" modern yang ada sebelum dan sesudah Madjid, khususnya pemikir Islam liberal di Indonesia. Untuk tujuan itulah makalah ini hadir, guna memilih dan memilah mana pemikiran yang tampak terjangkiti ide-ide dasar sekularisasi dengan coraknya relatif, skeptis dan agnostik. Dalam artikel ini penulis akan mengelaborasi sejarah singkat, pola pikir, ide dasar pemikiran Madjid dan pengaruhnya pada retorika tulisan cendekiawan Muslim setelahnya, khususnya tokoh-tokoh liberal di Indonesia pada paruh akhir abad ke-20. Oleh karenanya, penulis menilai perlu kiranya untuk menyuguhkan definisi sekularisasi, serta diharap darinya dapat dilacak elemen-elemen lain yang berkaitan.

\section{Metode Penelitian/Metode Kajian}

Penelitian ini merupakan penelitian kualitatif, yang berfokus pada kajian pustaka (library research). Pendekatan yang dipergunakan adalah deskriptif-analisis-kritis dengan memanfaatkan kajian filosofis sebagai pisau analisis utama dalam objek yang menjadi main concern. Teori yang dipergunakan adalah teori integrasi keilmuan. Sistematika penelitian ini diawali dari pelacakan sumber-sumber primer berupa karya utama dari tokoh yang dikaji, untuk kemudian dibandingkan dan kontraskan dari pelbagai sudut pandang, dalam ruang lingkup filosofis.

\section{Hasil dan Pembahasan}

\section{Integrasi Politik}

Jika ditelusuri sejarah perkembangan pemikiran politik Islam di Indonesia, maka akan ditemukan bibit-bibit "pembaharuan" telah ada sejak zaman kolonialisme Belanda. Namun sistematika yang berkembang saat itu belum "secanggih" seperti medio pertengahan akhir abad ke-20, tepatnya sekitar tahun 1970-an. Dawan Raharjo menyebut Nurcholis Madjid sebagai seorang tokoh pemukul gong pertama lahirnya liberalisasi sebagai usaha pembaharuan pemikiran Islam saat itu. Tepatnya pada 3 Januari 1970 melalui sebuah makalah berjudul "Keharusan Pembaruan Pemikiran Islam dan Masalah Integrasi Umat." (Madjid, 1987, p. 18) Dalam karyanya itu, cendekiawan yang akrab disapa Cak Nur tersebut secara tegas melempar pandangan atas keniscayaan sekularisasi Politik Islam guna menjawab tantangan zaman. Di situ, ia jelas menyatakan, bahwa: 
"Pembaruan harus dimulai dengan dua tindakan yang satu sama lainnya erat berhubungan, yaitu melepaskan diri dari pada nilai-nilai tradisional dan mencari nilainilai yang berorientasi kepada masa depan. Nostalgia atau orientasi dan kerinduan masa lampau yang berlebihan harus digantikan dengan pandangan ke masa depan. Untuk itu diperlukan suatu proses yang untuk mudahnya kita namakan proses liberalisasi. Proses ini dikenakan terhadap ajaran-ajaran dan pandangan-pandangan Islam yang ada sekarang ini. Proses ini menyangkut proses-proses lainnya". (Madjid, 1970, p. 2)

Caranya imbuh Nurcholish, melalui tiga proses yang saling terkait dan harus dilakukan yaitu; sekularisasi, kebebasan berpikir (intellectual freedom), dan sikap terbuka disertai gagasan tentang perkembangan.

Ketiga proses tersebut tampaknya diilhami oleh The Secular City, karya Harvey Cox. Pada tahun 1967-an The Secular City sendiri merupakan karya tulis yang paling banyak diminati, khususnya oleh kalangan Protestan, bahkan dalam konsili Vatikan kedua buku ini menjadi pembicaraan hangat oleh tokoh pesertanya. Ide dasar Cox mencakup tiga hal; pengosongan dunia dari nilai-nilai ruhani dan agama (disenchantment of nature), desakralisasi politik (desacralization of politics) dan penyingkiran nilai-nilai "otoritas" (deconsecration of values). Pertama, disenchantment of nature merupakan suatu pandangan bahwa manusia harus mampu mengeksploitasi alam secara optimal, tanpa dibatasi suatu pandangan atau keyakinan apapun. Kedua, desacralization of politics mengajarkan penyingkiran unsur rohani dan agama dari politik. Poin inilah tampaknya yang menarik Cak Nur untuk menyatakan "Islam Yes, partai Islam No." Ketiga, deconsecration of values mengajarkan bahwa kebenaran bermakna relatif, tidak ada nilai-nilai yang mutlak. Oleh karena pola pikir seseorang terus berubah seiring terus terjadinya perubahan faktor sosial dan budaya, maka tidak ada yang berhak untuk memaksakan sistem nilainya ke atas orang lain (Cox, 1967, p. 21).

Melalui tulisannya "Keharusan Pembaruan Pemikiran Islam dan Masalah Integrasi Umat," Madjid menegaskan titik tolak pembaharuan politik Islam harus berangkat dari pelepasan diri dari nilai-nilai tradisional serta mencari unsur-unsur lain yang berorientasi kemasa depan. Ide utama yang Madjid tampakkan dalam artikel tersebut adalah sekularisasi, kebebasan berpikir, serta mengenai perkembangam dan sikap terbuka. (Madjid, 1987, pp. 206-211) Poin yang menarik dalam hal ini adalah ketika menjelaskan sekulerisasi, Madjid membedakannya dengan sekulerisme. Baginya sekulerisasi merupakan liberating 
development, oleh karenanya ia tidak sama dengan sekularisme yang merupakan sebuah ideology, yang konotasinya a new closed world view which function very much like a new religion. Dalam Islam, Kemodernan dan Keindonesiaan, Madjid menganalogikan perbedaan kedua hal tersebut seperti perbedaan antara rasionalisasi dan rasionalisme. (Madjid, 1987, pp. 219-220) Artinya, sekularisasi yang dimau Madjid adalah suatu proses pemisahan antara agama sebagai dogma yang paten tempatnya dalam diri tiap individu, dan pemikiran keagamaan sebagai hasil kontemplasi pemikiran manusia yang selalu berubah dan adaptif terhadap perubahan zaman.

Meskipun artikel Cak Nur tersebut sangat sederhana -berkisar 6 lembar, namun lontaran pemikirannya menuai respon yang beragam. Baik dari sesama cendekiawan yang pro ataupun kontra semisal Daud Rosyid, Rasyidi, Djohan Efendi dan Endang Saefuddin Anshari, (Rachman, 2006, pp. 123-124) maupun pihak pemerintah yang menurut Kamal Hassan telah "diuntungkan" oleh ide Nurcholis ini. Gerakan sekularisasi pada masa itu menurut Hassan dianggap sebagai jawaban persoalan Bangsa, (Hassan, 1982) oleh karenanya, tidak heran ide Cak Nur ini dinilai cepat tumbuh berkembang dalam sejarah perkembangan pemikiran Islam di Indonesia, khususnya akhir abad ke-20. (Akmal, 2019, p. 364) Semenjak kejadian itu, dunia pemikiran Islam liberal di Indonesia menjadi lebih "hidup dan berani" dalam mengkaji kembali beberapa permasalahan yang dinilai sudah "mapan." Nurcholis tampaknya telah membuka pintu masuk bagi arus sekularisasi dan liberalisasi bukan hanya sebatas dalam makna sosiologis namun telah merambah filosofis, seperti halnya yang terjadi pada tradisi Yunani dan Kristen, yang dimulai dengan perubahan pola fikir, atau dalam bahasa al-Attas worldview (Smart, t.t.; al-Attas, 1995, p. 1) pemeluknya.

Adanya persinggungan pemikiran seperti digambarkan di atas, -dalam perspektif Amin Abdullah bagai pisau bermata ganda; di satu pihak ia menjadi "oase" di tengah kekeringan ilmiah, namun di sisi lainnya ia bagai air garam yang menebar ancama dan semakin memperparah rasa dahaga keilmuan. Peran pertama berjalan saat sentuhan tersebut telah secara langsung memperkaya warna dan corak khazanah keilmuan ataupun pendekatan kajian ilmiah dalam Islam, sebaliknya peran kedua hanya akan melahirkan perspektif projectionists, yang menempatkan agama sebatas fenomena sosial. (Abdullah, 2004, p. 31) Sakralitas dan unsur normative hanya menjadi sebatas ritual keagamaan, sedangkan budaya politik menjadi dimensi yang diutamakan.

Menarik benang merah keduanya, tidak sulit untuk menemukan adanya persilangan pendapat dalam memaknai kepastian atau kebenaran sebagai titik di mana kedua "mata pisau" di atas bertemu. Hal semacam ini dapat kita maklumi, karena setiap keyakinan 
membutuhkan suatu kepastian, seperti halnya Lotrop Stodard ketika mengaitkan Islam dan budaya Belanda, baginya: keselamatan daerah jajahan Belanda sangat bergantung pada penyebaran budaya Barat dan Belanda di tengah penduduk Muslim kepulauan itu. Penduduk daerah jajahan Belanda harus berorientasi seperti Belanda. Karena itu keberhasilan dalam menanamkan kebudayaan Belanda, akan mampu mengalahkan pengaruh agama Islam dalam jiwa pemeluknya. Tujuannya tiada lain adalah menyingkirkan perbedaan Belanda dengan Muslim Jawa ataupun Sumatera, jika suatu saat mereka akan menjadi warga Belanda. (Stodard, t.t., p. 342) Ungkapan Stodard tersebut secara tidak langsung telah menggambarkan bagaimana ia memandang arti penting pemisahan agama dan budaya, dalam proses interaksi kemasyarakatan atau bahkan perluasan kekuasaan.

Menanggapi hubungan antara pemikiran Islam dengan budaya ataupun keyakinan lain yang berkembang di Indonesia, Majid dalam karyanya "Pijakan Keimanan Bagi Fiqih Lintas Agama" menulis:

"Bagi masyarakat Kapitalis modern, menggunakan simbol-simbol keagamaan, seperti fiqih, merupakan cara untuk mengembangkan kapital, sebagaimana tercermin dalam maraknya bank-bank yang menggunakan simbol keagamaan... jadi fiqh merupakan khazanah yang diperebutkan, karena di dalamnya tersimpan semangat teosentrisme. Lalu apa yang terjadi bila fiqih bercorak teosentris?... kita akan masuk dalam jebakan otoritarianisme. (Madjid, 2004, p. 134)

Di sini tampak jelas bahwa Madjid melihat suatu penyalahgunaan agama oleh oknumoknum tertentu demi mencapai tujuan. Adanya penyelewengan inilah yang menurutnya berbahaya. Sebab ia menjadi landasan justifikasi kepentingan pribadi, syari'ah menjadi hanya jargon, dan fiqh sebagai hukum yang menjelaskan aspek-aspek teosentris menjadi barang dagangan. Oleh karena itu, untuk menjaga ontentisitas fiqh yang teosentris perlu diupayakan suatu pendekatan baru dalam fiqh, yaitu fiqh yang non-teosentris atau figh yang bercorak antroposentris. Meminjam istilah Protagoras fiqh yang standarnya dibangun di atas kemanusiaan, yang tentu saja yang "manusia adalah ukurannya."

Di sini penulis melihat bagaimana kesesuaian analogi pada ungkapan tersebut dengan apa yang diilustrasikan oleh Shabir Akhtar, yang intinya mengatakan bahwa "kepercayaan" sebagai titik pusat dari perbedaan. Akhtar menganalogikan secara singkat perspektifnya mengenai wacana Islam dan kultur dalam sebuah argumentasi singkat, yaitu ada dua jalan bagi seseorang untuk dapat memiliki rumah (baca: agama). Pertama, dengan tinggal dan berdiam di dalamnya. Cara ini bagi Akhtar merupakan keyakinan mayoritas masyarakat. 
Sebab hal ini dinilai paling memberi keamanan dan kenyamanan. Adapun cara kedua, yang lebih ideal untuk dikerjakan adalah agar Muslim meninggalkan rumah tersebut, guna hidup mengembara di "dunia" asing yang penuh akan perbedaan dan pertentangan budaya terhadap akidah Islam, untuk pada akhirnya kembali pada ke rumah iman. (Kurzman, 2003, pp. 551552) Keserasian analogi Sabhir dengan ide Cak Nur terletak pada penggunaan analogi "untuk melihat hutan secara keseluruhan, jangan berada di dalam hutan itu." Sampai di sini dapat kita simpulkan bahwa Cak Nur melihat "agama" sebagai pusat grafitasi perselisihan pendapat antar umat manusia, oleh karena itu tidak sepatutnya seseorang mengklaim agamanya yang paling benar, sebab semuanya agama pada intinya menyembah satu Tuhan yang sama. (Grose \& Hubbard, 1999, p. xix; Fautanu, M., \& Gunawan, 2020, p. 97)

\section{Sakralitas dalam Sosio-Politik}

Ada sebuah ungkapan menarik yang dilontarkan Daud Rosyid, salah seorang pakar hadis di Indonesia pada tahun 90-an. Dalam kritikannya atas Madjid ia menyatakan bahwa; "Sihir-sihir Nurcholish lebih canggih dan lebih memukau daripada Harun..." Membaca ungkapan tersebut, sekilas penulis merasa penasaran tentang apa sebenarnya yang dimaksud "sihir-sihir" dalam ungkapan itu?, namun jawabannya muncul dari kalimat terusan dari ungkapan itu, yaitu: “dikemas dengan gaya ilmiah yang menarik." Meskipun kemasan bukanlah produk utama dari komoditi "dagangan," namun dengan penampilan yang menariklah sebuah produk akan laku di pasaran. (Rosyid, 1993, pp. 11-15) Berangkat dari matriks Rosyid itu, penulis mencoba menelusuri beberapa karya yang berhubungan dengan Madjid hingga sampai pada tiga penggal tulisan Madjid, yang penulis nilai berkaitan dengan ungkapan Rosyid tersebut, yaitu;

“...sebagai konsekuensi logis dari tauhid. Pemutlakan transendensi semata-mata kepada Tuhan, sebenarnya, harus melahirkan desakralisasi pandangan terhadap selain Tuhan, yaitu dunia dan masalah-masalah serta nilai-nilai yang bersangkutan dengannya. Sebab, sakralisasi kepada sesuatu selain Tuhan itulah, pada hakikatnya, yang dinamakan syirik, lawan tauhid. Maka, sekularisasi itu memperoleh maknanya yang konkret, yaitu desakralisasi terhadap segala sesuatu selain hal-hal yang benarbenar bersifat ilahiyah (transendental, yaitu dunia ini).” (Madjid, 1987, p. 208)

"Sebagai sebuah pandangan keagamaan, pada dasarnya Islam bersifat inklusif dan merentangkan tafsirannya ke arah yang semakin pluralis. Sebagai contoh, filsafat perennial... merentangkan pandangan pluralis dengan mengatakan bahwa setiap agama sebenarnya merupakan ekspresi keimanan terhadap Tuhan yang sama. Ibarat 
roda, pusat roda itu adalah Tuhan, dan jari-jari itu adalah jalan dari berbagai Agama. Filsafat perenial juga membagi agama pada level esoterik (batin) dan eksoterik (lahir). Satu Agama berbeda dengan agama lain dalam level eksoterik, tetapi relatif sama dalam level esoteriknya. Oleh karena itu ada istilah "Satu Tuhan Banyak Jalan."” (Grose \& Hubbard, 1999, p. xix)

"Jadi Pluralisme sesungguhnya adalah sebuah aturan Tuhan (Sunnat Allah, "Sunnatullah") yang tidak akan berubah, sehingga juga tidak mungkin dilawan atau diingkari." (Madjid, 1995, p. 1xxvii)

Ada dua hal yang menarik dari beberapa ungkapan Cak Nur tersebut, yaitu; pengagungan unsur-unsur transendental dan desakralisasi profan sebagai dampak sekularisasi. Desakralisasi seperti ini terdengar "halus," terlebih lagi dilengkapi dengan ungkapan "selain hal-hal yang benar-benar bersifat ilahiyah.” Apa yang Madjid maksud halhal yang bersifat ilahiyah merujuk pada agama sebagai suatu jalan hidup dan keyakinan individu tanpa memaksakan kepada orang lain. Ia bersemayam dalam sanubari manusia, ia tidak berwujud suatu hukum sosial yang harus diikuti oleh semua orang, namun lebih kepada suatu sikap inklusif yang mampu mempersatukan seluruh aspek dan golongan masyarakat, ia menjunjung tinggi nilai-nilai humanis, toleran dan penuh penghormatan atas pendapat yang berbeda dari berbagai macam kaum beragama. Hal ini tampak jelas dalam ungkapannya bahwa "agama sebenarnya merupakan ekspresi keimanan terhadap Tuhan." Singkatnya, desakralisasi sebagai "Sunnatullah" merupakan usaha me"manusia"kan segala macam dogma yang ada, tujuannya; humanisasi, toleransi, kedamaian dan keadilan sosial bagi seluruh umat manusia.

Sejarah mencatat desakralisasi produk budaya yang digalakkan Madjid tersebut bukanlah hal baru. Sebagaimana diketahui, di Amerika sendiri ide ini telah massive diperbincangkan. Ia lahir dipelopori oleh Harvey Cox dengan disenchantment of nature-nya. Ide ini melahirkan demarkasi antara agama dan keberagamaan, antara agama dalam diri pribadi dan agama dalam sosial bermasyarakat, serta antara agama yang absolut lagi sakral dan penafsiran agama yang relatif lagi berubah-ubah. (Cox, 1967, p. 21) Dari itu semua, ungkapan yang dinilai paling mewakili perspektif ini, adalah "jangan menyucikan pemikiran keagamaan, sebab ia merupakan produk manusia, produk budaya dan terlebih lagi tidak sakral, sebagaimana agama itu sendiri."

Dalam konteks sosial politik kemasyarakatan, Madjid menulis bahwa demokrasi bukanlah kata benda, ia lebih merupakan sebuah kerja yang mengandung makna suatu proses 
berkesinambungan. Suatu proses yang secara dinamis bergerak menuju kesempurnaan. (Madjid, 2000, p. 32) Karenanya demokrasi merupakan suatu praktik pelaksanaan nilai-nilai keberadaban (civility) dalam bermasyarakat, berbangsa dan Negara. Hal ini berarti bahwa secara umum masyarakat yang berdemokrasi sama halnya dengan kebudayaan sosial yang terus berkembang ke arah kemajuan. Namun tentunya arah perkembangan tidak mungkin untuk selalu sama. Ia berkembang sesuai kebutuhan, nilai-nilai, norma, serta situasi dan kondisi dengan tidak melupakan adat istiadat yang telah mengakar sebelumnya. Dengan demikian arah perkembangan ke arah kemajuan atau disebut dengan pembangunan, tidak selalu mengarah ke kebudayaan Barat yang sering diidentikkan dengan modernisasi.

Jika dikaitkan antara bagaimana Madjid memandang pemikiran keagamaan dan sosialpolitik kemasyarakatan, maka dapat diartikan bahwa modernisasi bukanlah westernisasi melainkan gerakan rasionalisasi, sebuah proses pendewasaan rasio yang arah perubahannya sangat bergantung pada perubahan pandangan masyarakat. Madjid juga menekankan perlu atau tidaknya suatu gerakan modernisasi. Baginya jika sosial masyarakat yang sedang berkembang beranggapan tidak perlu mengikuti modernisasi, maka ia tidak diperlukan, namun sebaliknya jika mereka merasa perlu untuk mengejar guna mencapai sejumlah tujuan maka hal ini tidak bisa dielakkan. (Madjid, 1987, p. 197) Inilah kenapa gerakan modernisasi sosial sangat dipengaruhi oleh kebutuhan, situasi, kondisi, nilai-nilai, norma dengan tidak melupakan adat.

Oleh karena modernisasi merupakan fenomena perubahan sosial budaya, tentunya paradigm yang berjalan tidaklah sama dengan paradigm keagamaan. Dalam sains sosial meminjam istilah Durkheim, perubahan sosial bercirikan solidaritas mekanik menuju masyarakat yang bercirikan solidaritas organik. (Veeger, 1993, p. 140) Artinya dalam sosial berlaku prinsip analisa menyeluruh dengan memperhatikan konsekuensi peran dari tiap bagian guna mencapai keadaan normal yang memenuhi persyaratan sistem. Sedangkan dalam keagamaan, prinsip paradigma yang berjalan cenderung top down. Artinya bagianbagian suatu sistem wajib menyesuaikan dengan prinsip-prinsip tersebut. Oleh karena itu, akan ditemukan suatu titik di mana kedua paradigma itu tidak sesuai.

Untuk itu, bagi Madjid hubungan sosial dengan keagamaan merupakan hubungan yang saling melengkapi. Keduanya merupakan suatu organisme hidup yang berkembang sesuai dengan denyut nadi perkembangan manusia, tidak seharusnya satu mengeliminasi lainnya, terlebih lagi keduanya memiliki paradigma dasar yang berbeda. Jadi dengan meletakkan sosial dan agama sebagai "organisme hidup," Madjid secara tidak langsung ingin mengatakan bahwa Islam merupakan agama yang lahir dan berkembang sebagai hasil dari 
persinggungan manusia dengan budaya, manusia dengan alam dan manusia dengan manusia lainnya. Lebih jauh dapat kita katakan bahwa ungkapan ini telah secara langsung ingin melegalkan proses yang dinilainya sebagai "memanusiakan" nilai-nilai agama, atau bahkan agama itu sendiri. Sikap seperti ini secara tegas ingin menolak tradisionalisme (tekstualitas) secara mutlak dan menggantinya dengan kontekstualitas. Ia berusaha mengganti nilai-nilai lama dengan yang baru dengan menyatakan bahwa tradisi dan modernitas adalah sebuah proses yang kontinu.

Secara singkat, untuk menjelaskan hubungan agama dengan budaya saintifik dapat kita gambarkan dalam bagan berikut:

\section{Gambar 1. Bagan Persinggungan Asumsi.}

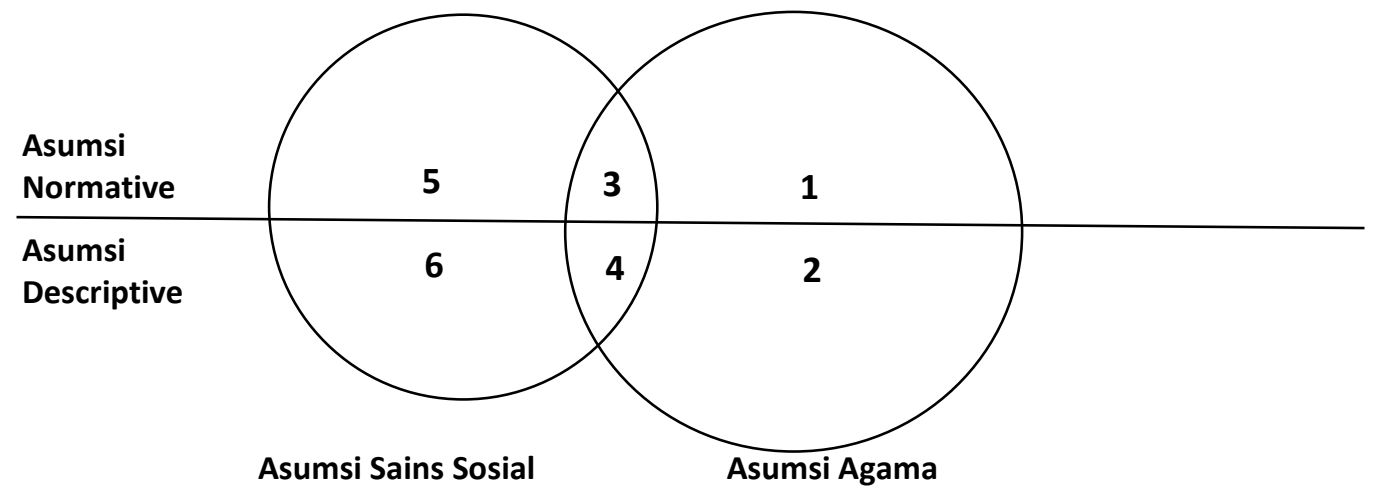

Bagan tersebut memvisualkan relasi antara beberapa asumsi dasar sekularisasi. Angka 1 dan 2 menunjukkan persoalan pribadi, angka 3 sampai 6 masalah umum. Persoalan umum amat sering kali berubah seiring perubahan sejarah manusia. Contoh yang disuguhkan Madjid sebagai mana dibahas sebelumnya adalah ungkapan Islam Yes, Partai Islam no. Kata "Yes" yang melekat pada Islam merujuk pada wilayah persoalan nomor 3 dan 4, adapun kata "No" pada partai Islam merujuk pada penempatan partai Islam di wilayah nomor 1 dan 2 yang menurutnya dipaksa untuk ditempatkan pada area nomor 3 dan 4. Dalam perspektif Madjid arena 3 dan 4 merupakan daerah yang menerima asimilasi sekaligus sangat welcome akan modifikasi aspek-aspek penting, utamanya terkait disiplin ilmu pengetahuan yang masih dapat diterima Islam. Pada poin 5 dan 6 menggambarkan bahasan filosofis yang sangat berlawanan dengan area 1 dan 2. Jadi untuk menjaga independensi kedua wilayah tersebut, maka tidak sepantasnya keduanya untuk dipaksa agar sama. (Mustofa, 2019, p. 283)

Dari sini dapat diartikan bahwa apa yang dimaksud Madjid tampaknya merupakan liberalisasi "pemikiran" keagamaan, atau lebih tepatnya dekonstruksi unsur-unsur agama dalam sosial masyarakat. Salah satu bentuk dekonstruksi ini adalah pemisahan agama dengan pemikiran agama. (Stodard, t.t., p. 342) Agama itu sakral dan merupakan urusan 
pribadi, adapun pemikiran agama hanyalah sebatas sangkaan belaka, oleh karenanya kedua hal tersebut tidak boleh dibawa-bawa ke dalam aspek sosial-politik, jadi "Islam yes, partai Islam no."

Setelah agama dijauhkan dari sosial masyarakat, dan pemikiran agama yang berada dalam ranah paradigma sains yang selalu berubah-ubah, maka pendukung sekularisasi akan mendorong untuk menyatakan bahwa ukuran agama tempatnya ada dalam kegiatan individu, sedangkan kegiatan sosial menggunakan paradigma relativis yang tidak mutlak. Di sini rasio sebagai pemegang otoritas utama dalam paradigma sains sosial mengambil perannya. Sedangkan dogma dalam kehidupan manusia juga merupakan bagian dari proses perkembangan sejarah, yang secara tidak langsung harus tunduk pada perubahan zaman. Singkatnya, hidup bersosial harus mampu menuruti rasio dan konsensus serta kebutuhan manusia. Hal ini merupakan dampak logis dari dekonstruksi unsur-unsur transenden agama dari sosial masyarakat, yang ujung-ujungnya akan mengatakan bahwa segala sesuatu yang "ada" di dunia ini niscaya akan berubah, satu-satunya yang tidak berubah adalah perubahan itu sendiri.

\section{Spekulasi "Roda" Keagamaan}

Sebagaimana diskursus di atas, salah satu ciri khas pemikiran Madjid dan pendukung sekularisasi adalah gayanya yang merelatifkan suatu "produk pemikiran" sebagai kebenaran parsial. Hal ini timbul sebagai akibat berkembangnya kesadaran untuk mendikotomi dan mendialogkan agama dengan pemikiran agama, budaya dan politik, baik dalam segi substansi ataupun dataran aksinya. Pemikiran agama pada dasarnya dipandang sebagai relatively absolute atau sebaliknya absolutetly relative. Dampaknya, agama diharapkan mampu mengambil peran sebagai pembebas kemanusiaan. Salah satu bentuk penegasan hal ini dituangkan oleh Madjid dalam suatu orasi ilmiah dalam rangka peringatan 20 tahun pembaharuan Islam. Dalam salah satu bagian artikel yang ia bacakan menegaskan bahwa sebagaimana sebagian Muslim menilai agama lain sebagai sebuah kesalahan dan kepalsuan, maka non-Muslim juga berpendapat persis sama, hanya saja dengan nilai yang terbalik. Bagi mereka apa yang dianggap orang Islam benar; merupakan sebuah kepalsuan, dan apa yang palsu merupakan sebuah kebenaran. Bagaikan bayangan di cermin, kanan jadi kiri, dan kiri jadi kanan. Kemudian ada juga pihak ketiga yang melihat perselisihan kita dengan lawan sebagai sebuah sikap saling menghancurkan antara dua kepalsuan. Hal ini, bagi Madjid merupakan suatu dilema, sebab agama yang seharusnya membawa kebaikan, justru menjadi justifikasi kebenaran individu lagi melahirkan intoleransi. (Madjid, 1993) Pemikiran seperti 
inilah yang "menghantui" Madjid dan membawanya ke dalam lingkaran pencarian makna dan nilai-nilai kebenaran yang berakhir pada kebenaran sains dan kebenaran agama.

Sikap keragu-raguan ini mirip seperti apa yang dialami Xenophanes salah seorang tokoh Sophis sekitar tahun 550-an SM. Dalam The Story of Philosophy karya Brayan Magee, Xenophanes mengungkapkan bahwa kebenaran yang pasti tidaklah diketahui oleh seorangpun. Entah tentang dewa-dewa atau tentang segala hal yang ku katakan, kalaupun harus mengungkapkan kebenaran terakhir, ia sendiri tidak mengetahuinya, sebab segalanya hanya prasangka dan dugaan belaka. Inilah kenapa jika Ethiopia menggambarkan dewadewa berhidung pesek berkulit hitam, orang Thracia melihat mereka berambut merah, dan seandainya hewan semisal sapi, kuda dan kerbau mampu menggambarkan dewa mereka, maka pastinya dewa akan mereka gambarkan mirip seperti diri mereka. Setiap masingmasing akan melukiskan dewa-dewa seperti bentuk tubuh mereka sendiri. (Magee, t.t., p. 16)

Dari pemikiran Madjid dan Xenophanes ditemukan satu kesamaan ide, yaitu terletak pada persamaan sangkaan bahwa hasil penafsiran agama atau hasil pemikiran keagamaan hanyalah sebatas "sangkaan" manusia. Perspektif ini juga diamini oleh Heraclitus dengan menganalogikakan relativitas kebenaran dengan cara yang cukup unik, yaitu; kebenaran bagaikan air laut, yang dalam satu segi ia merupakan sumber kehidupan bagi ikan, namun akan menjadi bencana bagi manusia manakala diminum. Artinya, sikap ini tampaknya menuntut pemikiran agama sebagai "wasit" bukan "pemain," ia boleh menilai, melihat bahkan menghakimi, namun tidak boleh ikut bermain. Pemikiran hanyalah suatu manifestasi olah pikir manusia, oleh karenanya produk kebenaran yang dikeluarkan tidak mengikat. Selain itu, ungkapan "semua adalah relatif" menjadi suatu tren berpikir tersendiri. Dampaknya, lahirlah ungkapan-ungkapan semacam "berpikirlah dengan benar, tapi jangan merasa benar, sebab kebenaran itu relatif;" "benar itu menurut anda, namun belum tentu bagi kami;" akhirnya "kalau kamu mengimani suatu hal, jangan merasa yakin bahwa keimanan anda itu yang paling benar, sebab keimanan orang lain bisa jadi lebih benar.” Intinya, semua akan digiring menjadi hanya sebatas "merasa benar," namun bukan realitas kebenaran hakiki.

Merasa benar menjadi tabu, apalagi merasa paling benar sendiri adalah "dosa." Hal inilah yang tampaknya memaksa Joseph Runzo untuk berujar "we live in an age of Relativism.” (Runzo, 1986, p. 10) Setiap orang harus bersikap "adil” dan tidak memihak apalagi merasa paling benar sendiri. Akhirnya, timbul pertanyaan jika keberpihakan itu "haram," maka bagaimana seseorang dapat berpihak pada suatu kebenaran yang ia yakini, 
padahal kebenaran itu sendiri masih diragukan?. Pertanyaan ini jika kita biarkan untuk terus mengalir, maka tidak mustahil akan sampai pada suatu titik di mana "jika keadilan yang kita yakini masih diragukan, maka seperti apakah keadilan yang seharusnya kita ikuti?.” Tidak hanya berhenti di sini, perspektif semacam ini juga akan berimplikasi pada seluruh tata nilai kehidupan, puncaknya tidak mustahil hal-hal semacam konsep keadilan, hak asasi, toleransi, hukum, Negara, gender bahkan agama akan menjadi penuh "bias."

Untuk menjawab persoalan di atas, Cak Nur mencoba mengajak untuk menerima cara pandang yang berbeda dari mainsream; yaitu tidak merasa paling benar. Pendapat Xenophanes bahwa "kalaupun harus mengungkapkan kebenaran terakhir, ia sendiri tidak mengetahuinya, sebab segalanya hanya dugaan demi dugaan belaka," (Magee, t.t., p. 16) tampak diamini Madjid menjadi "mereka yang ada dipihak lawan agama kita juga berpendapat persis sama, hanya saja dengan nilai yang terbalik: benar menjadi palsu, dan palsu menjadi benar.” (Madjid, 1993, p. 25) Keduanya mengandung pengertian, bahwa; sama seperti sains, tidak ada produk "kebenaran" pemikiran agama yang benar-benar valid dan berlaku kontinu. Keduanya merupakan produk persangkaan manusia, yang selalu berkembang mengikuti sejarah, yang selalu berubah dan relative. Dampaknya, Muslim dituntut untuk meyakini bahwa orang beragama apa pun selagi mampu menjalankan ajaran agamanya dengan baik, maka ia seperti seorang Muslim yang taat pada tuntunan syariah. Oleh karenanya, sesama pemeluk agama dengan beragam ritual hendaknya harus bersikap toleran untuk dapat bersama-sama mengakui kebenaran seluruh agama, di samping juga harus meragukan validitas yang diklaim final oleh agama sendiri. Dengan demikian apa yang menjadi konsep pola pikir semacam ini adalah memperjuangkan Islam Inklusif, pluralis atau toleran tidak hanya dalam wilayah fisik bahkan dalam wilayah akidah dasar (metafisik).

Seperti halnya sebuah roda, pusat roda itu adalah Tuhan, dan jari-jari itu adalah jalan dari berbagai Agama. Filsafat perenial juga membagi agama pada level esoterik (batin) dan eksoterik (lahir). Satu Agama berbeda dengan agama lain dalam level eksoterik, tetapi relatif sama dalam level esoteriknya. Gagasan utama dalam ide ini menyebutkan bahwa nama agama dapat berbeda-beda, seperti Islam, Kristen, Budha, namun sejatinya inti dari semua agama itu sama dan satu, yaitu menyembah zat yang sama dan Mutlak yang disebut Tuhan. Oleh karena itu ada istilah "Satu Tuhan Banyak Jalan.” Jadi, pluralisme sesungguhnya adalah sebuah 'sunnatullah' yang tidak akan berubah, dan tidak mungkin untuk ditolak.

Gagasan di atas dapat disimpulkan, bahwa mengklaim paling benar akan melahirkan ketidakharmonisan hidup, oleh karenanya kaum sekular menekankan perlunya melihat kebenaran dalam kemajemukan pemikiran keagamaan. Meskipun demikian, tidak dapat 
dipungkiri bahwa argumentasi yang disuguhkan cenderung untuk membela perilaku, tindakan ataupun moral masyarakat tertentu, namun tidak untuk memilah dan memilih kebenaran yang hakiki, sebab kebenaran hanya sekedar "sangkaan." Dengan begitu, sikap ini secara tidak langsung telah menyebarkan benih-benih anti otoritas. Barometernya adalah spekulasi akademis personal. Oleh karenanya, corak pemikiran ini selalu menekankan pada ungkapan-ungkapan "jangan terlalu yakin," "anda boleh jadi salah," "jadilah orang yang tolerant dan berpikiran terbuka," (Titus, Smith, \& T., 1984, p. 233) sebab banyak orangorang ahli dalam segala bidang pun mempunyai keragaman pendapat yang berbeda-beda, bahkan saling kontradiktif. Akhirnya, relativitas absolut akan membawa kepada kepercayaan hanya pada pengalaman pribadi, tidak yang lain, atau bahkan merelatifkan semuanya. Hal-hal seperti norma, nilai dan makna dalam hidup hanya "numpang lewat." Singkatnya, sikap ini ingin menyatakan bahwa manusia tidak dapat mencapai kebenaran dan tidak dapat mengetahui realitas yang hakiki. Lebih lanjut, hal ini tidak menutup kemungkinan untuk bersikap tidak percaya secara total kepada makna dan nilai-nilai kebenaran termasuk agama, dan konsep Tuhan.

\section{Fenomena Demarkasi "Makna"}

Dampak dari sikap merelatifkan hasil otoritas dan cenderung kepada kontemplasi keilmuan sebagaimana tampak di atas, adalah lahirnya sebuah proses pengkotak-kotakan makna atau nilai-nilai yang terkandung dalam unsur sosial-politik. Distorsi ini dapat berupa; sikap mau menerima kemungkinan kebenaran sains, namun menolak tujuan dan hakikat darinya, mau menerima Tuhan namun menolak "agama," ataupun sikap menafikan keberadaan suatu hal, dan menganggapnya sebagai suatu fantasi belaka yang mengakibatkan penolakan atas kemungkinan seseorang memperolah suatu ilmu pengetahuan yang benarbenar valid. (Al-Hujwiri, t.t., pp. 15-18) Contohnya apa yang dituturkan Madjid, bahwa jenis keagamaan yang tidak dapat diterima adalah agama yang memaksa seseorang untuk tunduk patuh kepada "sesama manusia," dan yang menjadikan dirinya terasing, meskipun hal itu dilakukannya dalam usahanya menyembah Tuhan. Hal ini disebabkan karena Tuhan dapat bermakna macam-macam.

Pernyataan Madjid juga diamini oleh sesama pendukung sekularisasi lainnya. Contohnya, Luthfi Assyaukanie pada harian Kompas, per tanggal 3 September 2005, ia menegaskan bahwa: "Seorang fideis Muslim, misalnya, bisa merasa dekat kepada Allah tanpa melewati jalur shalat karena ia bisa melakukannya lewat meditasi atau ritus-ritus lain yang biasa dilakukan dalam persemedian spiritual" dalam (Kompas, 3 September 2005) Jauh sebelum itu, pada tanggal 10 Mei 2001, dalam (Kompas, 18 Nopember 2001) Ulil Abshar 
juga menulis hal yang senada, baginya "masalah kemanusiaan tidak bisa diselesaikan dengan semata-mata untuk merujuk kepada "Hukum Tuhan" (sekali lagi; saya tidak percaya adanya "hukum Tuhan;" kami hanya percaya pada nilai-nilai keTuhanan yang universal)."

Bagi Madjid permasalahan duniawi harus diselesaikan melalui hukumnya masingmasing; bidang politik, ekonomi, sosial dan sebagainya mengenal hukumnya sendiri-sendiri. ia juga melanjutkan bahwa "yang ada adalah hukum manusia, bukan hukum Tuhan... apa pun penafsiran yang kita butuhkan atas agama itu, patokan utama yang harus menjadi batu uji adalah maslahat manusia itu sendiri. Seluruh pernyataan di atas menunjukkan tren berpikir yang sama, yaitu: mengedepankan aspek sosio-historis di atas normatif, anti kemapanan dan otoritas, transendenitas digusur oleh fiskal, ibadah tanpa aturan formal yang mengikat, serta cenderung kepada model pragmatis. (Popkin, 1967, pp. 449-461) Dari itu semua, tidak sulit untuk mengatakan bahwa dalam perspektif kaum sekular agama hanyalah salah satu penyumbang moralitas dan etika, oleh karenanya dogma dan doktrin sudah sewajarnya duduk diam dalam hati masing-masing individu. Perspektif semacam ini tampak berusaha menolak apa saja yang berbau normatif, tekstual, otoritarian kemudian menyimpannya dalam diri individu serta berusaha memunculkan sikap pragmatis. Sikap yang berorientasi pada maslahat kekinian. Oleh karenanya, -meminjam istilah Ulil, "yang ada adalah hukum manusia, bukan hukum Tuhan." Standar pertimbangan baik-buruk maupun benar-salah dikembalikan kepada konsensus masyarakat yang bersangkutan.

Jika ditarik ke dalam ranah filosofis, maka ada satu teori yang penulis lihat sejalan dengan perspektif ini, yaitu apa yang Karl R. Popper sebut sebagai "garis demarkasi." Garis yang membedakan antara mana yang ilmu pengetahuan dan mana yang bukan ilmu, antara yang ilmiah dan mana yang tidak ilmiah melalui kriteria-kriteria tertentu. Kriteria tersebut adalah; criticable, testable, refutable, dan falsifiable. (Taryadi, 1991, p. 49) Keempat hal tersebut memainkan peran penting dalam menentukan demarkasi antara ilmiah dan nonilmiah. Dalam logic of scientific discovery Popper, “demarkasi” tampaknya merupakan suatu bentuk usaha guna "menyelamatkan" agama, atau setidaknya menegaskan wilayah operasi agama maupun sains dalam pencarian makna. Popper memisahkan antara pernyataan yang bermakna dan yang tidak, dengan asas "falsifikasi." Semua pernyataan yang dapat difalsifikasi adalah ilmiah, sementara yang tidak adalah non-ilmiah. (Popper, 1965) Agama ditempatkan dalam wilayah non-ilmiah, sebab ia bukan termasuk sains, namun bukan berarti tidak bermakna. Sehingga meskipun hal-hal semacam agama, etika, estetika dan metafisika dinilai Popper "tidak ilmiah," namun tidak berarti tidak memiliki kandungan makna. Itulah 
kenapa barangkali kaum sekular selalu menggadang-gadangkan "agama merupakan urusan pribadi, sedangkan sosial urusan bersama, oleh karenanya sosial harus diutamakan.”

Jika dikaitkan sejarah "demarkasi” ini dengan sekularisasi yang berkembang pada saat itu, maka tidak berlebihan kiranya kalau kita katakan bahwa sekularisasi merupakan usaha untuk merekonstruksi kemapanan demarkasi antara sains dan non-sains dalam Islam, antara ilmiah dan non-ilmiah, antara bermakna dan tidak bermakna. (al-Jabiri, 2004, pp. 13, 251) Sekularisasi dikategorikan sebagai suatu seni berpikir diletakkan atau cabang sains yang selalu berkembang, di lain pihak agama dengan paradigma top-down-nya diposisikan sebagai unsur yang bermakna dalam hidup. Agama meskipun bermakna namun penerapannya dituntut untuk mampu menyesuaikan diri dengan tuntutan, kebutuhan bahkan tantangan zaman.

Dari keterangan di atas, dapat disimpulkan, bahwa sekularisasi merupakan suatu usaha "mendekonstruksi" segala macam wacana keilmuan. Penggiat sikap ini akan memisahkan antara dogma dan sains kehidupan sosial. Mereka juga melihat perbedaan antara paradigma dalam agama dan paradigma ilmu-ilmu sosial. Oleh karenanya, langkah paling tepat yang mereka tawarkan adalah "agama tempatnya ada di dalam individu masing-masing, sedangkan hukum-hukum yang berjalan dalam sosial kemasyarakatan adalah hukum konsensus bersama alias sains sosial." Tujuannya, sebagaimana diujarkan Muhammad Asad, adalah tidak mengakui keperluan manusia kepada apa pun kecuali tuntutan ekonomi-sosial dan kebangsaan. (Asad, 1983, p. 35) Singkatnya, sekularisasi merupakan langkah menuju penegasan kembali garis demarkasi yang telah coba dijelaskan oleh Popper (1965).

\section{Catatan Kritis}

Secara umum, dalam memaknai sekularisasi sebagai desakralisasi sains sosial, penulis melihat adanya usaha untuk menyamakan dua kategori “objek pembelajaran" dalam epistemology. Pertama, ada objek pembelajaran yang masuk dalam kategori milik bersama umat manusia. Maksudnya adalah nilai-nilai ataupun kesepakatan yang diamini oleh mayoritas manusia. Poin dalam ilmu mantik sering kita sebuah sebagai principle of identity ( $m a \bar{h} i y a h$ al-ittifāq), yaitu prinsip yang menggambarkan persamaan.

Kedua, ada juga wilayah yang menjadi spesialisasi kelompok, agama ataupun peradaban tertentu. Hal ini dikenal dengan istilah principle of difference (māhiyah al-iftirāq), yaitu prinsip yang membedakan suatu hal. Kategori pertama, dapat dicontohkan berupa sains; yang dalam sejarahnya "Barat" banyak belajar dari umat Islam, umat Islam mengkaji Yunani, dan Yunani belajar dari bangsa-bangsa Timur seperti Mesir dan India. (Mustofa, 
2019, pp. 238-242) Namun, dalam kategori kedua, yaitu dalam hal-hal spesialisasi, umat Islam tidak mengadopsi teologi ataupun mitologi Yunani, meskipun mempelajari pemikiran beberapa tokoh mereka. Hal serupa juga terjadi pada dunia Barat, yang tidak semata-mata mengadopsi akidah Islam. Masing-masing memiliki kekhasan jati dirinya. Keragaman kultur-budaya inilah yang didekonstruksi oleh tokoh-tokoh di atas, meski secara formal mendakwahkan pluralisme. Jadi, dekonstruksi di sini dapat diartikan sebagai upaya untuk menyamakan kedua kategori “objek pembelajaran” itu. (Atmaja, 2020, pp. 107-124)

Sikap menyamakan kedua "objek pembelajaran" semacam ini cenderung menyempitkan ruang lingkup agama pada permasalahan iman saja, tanpa amal apalagi framework berpikir. Iman menjadi hanyalah masalah hati dan personal. Artinya, tidak patut bagi seorangpun untuk dapat mengatakan bahwa iman orang lain benar ataupun salah. Uraian itu terasa logis, indah dan penuh akan toleransi. Jika tidak kritis terhadap pernyataanpernyataan di atas, maka tidak mustahil hal ini akan menjadi suatu "kebenaran" yang baru. Kebenaran yang membenarkan penyamaan antara sains dan iman, antara agama satu dengan yang lain, antara konsep Tuhan Islam dengan Kristen, Hindu, Budha dan sebagainya. (Mustofa, 2017, pp. 53-75)

Menarik jauh ke belakang, sikap "penyamaan” semacam ini pernah diutarakan oleh Herakleitus (540-an SM). Bryan Magee, dalam The Story of Philosophy menjabarkan pendapat Herakleitus bahwa realitas pada dasarnya tidak stabil. Segala sesuatu adalah flux, mengalir, secara terus menerus sepanjang waktu. Tidak ada sesuatu pun di dunia ini yang terus ada seperti adanya sekarang. Segalanya terus berubah sepanjang waktu. Berbagai hal muncul dengan berbagai cara, dan tidak pernah sama dalam dua titik waktu, hingga akhirnya mereka lenyap. Ungkapan ini diperkuat oleh Socrates, yang menurut Bryan Magee, berkeyakinan bahwa: "Tidak seorang pun yang karena ketidaktahuannya bisa dikatakan melakukan kesalahan. Maksudnya, kalau anda tahu betul bahwa sesuatu adalah salah, anda tentu tidak akan melakukannya. Sebaliknya kalau anda melakukannya, itu berarti bahwa anda belum betul-betul tahu bahwa itu salah.” (Magee, t.t., p. 16)

Ungkapan Socrates tampaknya ambigu dan dilematik, sebab jika seseorang berbuat salah karena tidak tahu, maka ia tidak dianggap salah, lantas jika ia sudah tahu namun tetap berbuat salah, maka berarti ia belum benar-benar tahu. Pernyataan semacam ini sendiri merupakan bentuk klaim bahwa tidak ada orang yang benar-benar tahu selama ia masih bisa berbuat salah, dan tidak ada kesalahan selama orang tidak tahu apa yang benar-benar valid. Tidak ada yang namanya kebenaran selama masih bisa diperdebatkan. Satu-satunya yang mutlak benar adalah kebenaran Tuhan, yang tidak diketahui oleh manusia dengan sekian 
banyak kekurangannya. Dampaknya, sekularisasi yang melahirkan desakralisasi secara tidak langsung telah menyamakan antara kebenaran Iman dan kebenaran sains yang terus berkembang, antara agama satu dengan yang lainnya, sebab semuanya menyembah "Tuhan" yang sama.

Sampai di sini dapat disimpulkan bahwa sikap penyamaan antara prinsip yang menggambarkan persamaan dan prinsip pembeda dalam suatu objek pembelajaran merupakan suatu intelctual impoverisment (pemiskinan intelektual). Sekularisasi yang digadang sebagai jawaban ilmiah, dalam pembaharuan pemikiran Islam, tampaknya malah menjadi "blunder" yang mengakibatkan demarkasi antara agama dan keberagamaan; antara agama dalam diri pribadi dan agama dalam sosial bermasyarakat; antara agama yang absolut lagi sakral dan penafsiran agama yang relatif lagi berubah-ubah. Dari itu semua, otoritas dan tradisi lama akan ditinggalkan, sedangkan ide-ide sekuler lagi "ilmiah" menjadi tren terbaru. Padahal meninggalkan unsur sakralitas dalam segala sendi kehidupan, serta hanya menuntut kepada suatu hal yang baru dengan cara mengambil yang pokok-pokok saja, tanpa memperhatikan keterkaitan satu unsur dengan yang lainnya merupakan suatu pengambilan kesimpulan yang loncat. Akhirnya sekularisasi lebih merupakan suatu usaha untuk menyamakan antara agama dan fenomena keberagamaan. Agama dibacanya melalui praktik keberagamaan yang berkembang pada masyarakat, oleh karenanya "Islam Yes, Partai Islam No."

\section{Penutup}

Terjadi multi tafsir dalam pendefinisian sekularisasi. Madjid mencoba membelah menjadi makna sosiologis dan filosofis. Makna sosiologis mengadopsi pemikiran Talcoot Parsons dan Robert N. Bellah, dan filosofis mengutip Harvey Cox. Dampak dari ide Madjid adalah desakralisasi agama dari pemikiran keagamaan. Prosesnya mencakup tiga hal: disenchantment of nature, desacralization of politics dan deconsecration of values. Meskipun demikian penulis melihat hadirnya satu kontemplasi dan usaha keras yang diperlihatkan Madjid dalam usaha menempatkan Islam dan para ulama' yang diklaim "otoritatif" bukan sebagai akumulasi norma dan ataupun tokoh "suci," namun melihat keduanya sebagai suatu teks yang interpretative. Hasilnya, upaya pembaharuan pemikiran Islam di Indonesia pada masa itu terkesan mencoba membawa makna dan tujuan ilmu serta beberapa konsep ilmu yang dimiliki umat Islam kepada pendekatan kebudayaan dan pandangan hidup khususnya paham, ide, nilai dan filsafat ilmu Barat modern dan postmodern. Meskipun demikian, sebagai sebuah ijtihad ilmiah, patut diapresiasi. 


\section{Daftar Pustaka}

Abdullah, M. A. (2004). Studi Agama Normativitas atau Historitas? Yogyakarta: Pustaka Pelajar.

Akmal, A. (2019). The Rise of \#IndonesiaTanpaJIL Youth Movement and the Fall of Liberal Islam on Cyberspace. Tsaqafah: Jurnal Peradaban Islam, 15(2), 363-374.

al-Attas, S. M. (1995). Prolegomena to The Metaphysics of Islam An Exposition of the Fundamental Element of the Worldview of Islam. Kuala Lumpur: ISTAC.

Al-Hujwiri, '. I. (t.t.). Kashf aI-Mahjūb. Lahore: Islamic Book Foundation.

al-Jabiri, A. (2004). Bunyah al-'Aql al-'Arabī. Bayrūt: Markaz Dirāsah al-Wahdah al'Arabīyah.

Asad, M. (1983). Islam di Simpang Jalan. Bandung: t.p.

Asyaukani, L. (3 September 2005). Kompas. Kompas.

Atmaja, A. K. (2020, July 29). Pluralisme Nurcholis Madjid dan Relevansinya terhadap Problem Dakwah Kontemporer. Jurnal Dakwah Risalah, 31(1). Retrieved July 29, 2021

Cox, H. (1967). The Secular City: Secularization and Urbanization in Theological Perspective. New York: The Macmillan Company.

Esposito, J. L., Tamimi, A., Keane, J., Elmassiri, A. W., Elmassiri, A., Manzoor, S. P., . . Davutoglu, A. (2000). Islam and Secularism in the Middle East. (J. L. Esposito, \& A. ETamimi, Eds.) New York: New York University Press.

Fautanu, I., M., B., \& Gunawan, H. (2020). Politik Identitas dalam Pilkada DKI Jakarta Tahun 2017: Perspektif Pemikiran Politik Nurcholish Madjid. Politicon: Jurnal Ilmu Politik, 2 (2).

Grose, G. B., \& Hubbard, B. J. (1999). Tiga Agama Satu Tuhan. Bandung: Mizan.

Hassan, M. K. (1982). Muslim Intellectual Responses to "New Order Modernization in Indonesia. Kuala Lumpur: Dewan Bahasa dan Pustaka.

Kurzman, C. (Ed.). (2003). Wacana Islam. Jakarta: Paramadina.

Madjid, N. (1970). Keharusan Pembaruan Pemikiran Islam dan Masalah Integrasi Umat. T.tp.: t.p.

Madjid, N. (1987). Islam Kemodernan dan Keindonesiaan. Bandung: Mizan.

Madjid, N. (1993). Beberapa Renungan tentang Kehidupan Keagamaan untuk Generasi Mendatang. Jurnal Ilmu dan Kebudayaan Ulumul Qur'an, 4(1), 24-25.

Madjid, N. (1995). Islam Doktrin dan Peradaban. Jakarta: Paramadina.

Madjid, N. (2000). Membangun Oposisi Menjaga Momentum Demokrasi. Jakarta: Voice Center Indonesia.

Madjid, N. (2004). Pijakan Keimanan Bagi Fiqih Lintas Agama. (M. A. Sirry, Ed.) Jakarta: Paramadina.

Magee, B. (t.t.). The Story of Philosophy. London: DK Publishing.

Mustofa, I. (2017, Juni). Fisika Atom sebagai Basis Filosofis Ilmu dalam Perspektif alGhazali. Epistemé: Jurnal Pengembangan Ilmu Keislaman, 12(1), 53-75. 
Mustofa, I. (2019). Gagasan Islamisasi Ilmu (Studi tentang Kerangka Metodologi Institute for the Study of Islamic Thought and Civilization (INSISTS)). Surabaya: Disertasi-UIN Sunan Ampel.

Nasution, H. (1997). Islam, Sekularisasi dan Sekularisme: Catatan atas Pemikiran Pembaruan Nurcholish Madjid. In H. Nasution, Islam Rasional (p. 189). Bandung: Mizan.

Pardoyo. (1993). Sekularisasi dalam Polemik. Jakarta: Grafiti.

Popkin, R. H. (1967). The Encyclopedia of Philosophy (Vol. 7). (P. Edwards, Ed.) New York: Macmillan.

Popper, K. R. (1965). Logic of Scientific Discovery. New York: Harper and Row, Harper Torchbooks.

Rachman, B. M. (2006). Nurcholish Madjid dan Perdebatan Islam di Indonesia, dalam Menembus Batas Tradisi, Menuju Masa Depan yang Membebaskan: Refleksi atas Pemikiran Nurcholish Madjid. Jakarta: Kompas.

Rahman, F. (1984). Islam and Modernity, Transformation of an Intellectual Tradition . London: The University of Chicago Press.

Rorty, R. (1980). Richard Rorty, Philosophy and The Mirror of Nature. Richard Rorty, Philosophy and The Mirror of NaturePrinceton: Princeton University Press.

Rosyid, D. (1993). Pembaruan Islam dan Orientalisme dalam Sorotan. Jakarta: Usamah Press.

Runzo, J. (1986). Reason, Relativism and God. London: Macmillah Press.

Smart, N. (t.t.). Worldview, Crosscultural Explorations of Human Belief. New York: Charles Sribner's sons.

Stodard, L. (t.t.). Hāọdir al- 'Ālam al-Islāmī (Vol. 1). Bayrut: Dār al-Fikr.

Taryadi, A. (1991). Epistemologi Pemecahan Masalah Menurut Karl Popper. Jakarta: Gramedia.

The Encyclopedia of Religion. (1995). In M. Eliade. New York: Simon dan Schuster.

Titus, H. H., Smith, M. S., \& T., . (1984). Persoalan-persoalan Filsafat. Jakarta: Bulan Bintang.

Veeger, K. J. (1993). Realitas Sosial Refleksi Filsafat Sosial Atas Hubungan IndividuMasyarakat dalam Cakrawala Sejarah Sosiologi. Jakarta: Gramedia. 
